\title{
Marine ecosystem community carbon and nutrient uptake stoichiometry under varying ocean acidification during the PeECE III experiment
}

\author{
R. G. J. Bellerby ${ }^{1,2}$, K. G. Schulz ${ }^{3}$, U. Riebesell ${ }^{3}$, C. Neill ${ }^{1}$, G. Nondal ${ }^{4,2}$, E. Heegaard ${ }^{1,5}$, T. Johannessen ${ }^{2,1}$, and \\ K. R. Brown ${ }^{1}$ \\ ${ }^{1}$ Bjerknes Centre for Climate Research, University of Bergen, Allégaten 55, 5007 Bergen, Norway \\ ${ }^{2}$ Geophysical Institute, University of Bergen, Allégaten 70, 5007 Bergen, Norway \\ ${ }^{3}$ Leibniz Institute for Marine Sciences (IFM-GEOMAR), Dusternbrooker Weg 20, 24105 Kiel, Germany \\ ${ }^{4}$ Mohn-Sverdrup Center and Nansen Environmental and Remote Sensing Center, Thormølensgate 47, 5006 Bergen, Norway \\ ${ }^{5}$ EECRG, Department of Biology, University of Bergen, Allégaten 41, 5007 Bergen, Norway
}

Received: 19 November 2007 - Published in Biogeosciences Discuss.: 13 December 2007

Revised: 3 September 2008 - Accepted: 3 September 2008 - Published: 10 November 2008

\begin{abstract}
Changes to seawater inorganic carbon and nutrient concentrations in response to the deliberate $\mathrm{CO}_{2}$ perturbation of natural plankton assemblages were studied during the 2005 Pelagic Ecosystem $\mathrm{CO}_{2}$ Enrichment (PeECE III) experiment. Inverse analysis of the temporal inorganic carbon dioxide system and nutrient variations was used to determine the net community stoichiometric uptake characteristics of a natural pelagic ecosystem perturbed over a range of $p \mathrm{CO}_{2}$ scenarios (350, 700 and $1050 \mu \mathrm{atm})$. Nutrient uptake showed no sensitivity to $\mathrm{CO}_{2}$ treatment. There was enhanced carbon production relative to nutrient consumption in the higher $\mathrm{CO}_{2}$ treatments which was positively correlated with the initial $\mathrm{CO}_{2}$ concentration. There was no significant calcification response to changing $\mathrm{CO}_{2}$ in Emiliania huxleyi by the peak of the bloom and all treatments exhibited low particulate inorganic carbon production $\left(\sim 15 \mu \mathrm{mol} \mathrm{kg}^{-1}\right)$. With insignificant air-sea $\mathrm{CO}_{2}$ exchange across the treatments, the enhanced carbon uptake was due to increase organic carbon production. The inferred cumulative $\mathrm{C}: \mathrm{N}: \mathrm{P}$ stoichiometry of organic production increased with $\mathrm{CO}_{2}$ treatment from 1:6.3:121 to $1: 7.1: 144$ to $1: 8.25: 168$ at the height of the bloom. This study discusses how ocean acidification may incur modification to the stoichiometry of pelagic production and have consequences for ocean biogeochemical cycling.
\end{abstract}

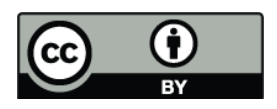

Correspondence to: R. G. J. Bellerby (richard.bellerby@bjerknes.uib.no)

\section{Introduction}

Consequent to the increase in the atmospheric load of carbon dioxide $\left(\mathrm{CO}_{2}\right)$, due to anthropogenic release, there has been an increase in the oceanic carbon reservoir (Sabine et al., 2004). At the air-sea interface, the productive, euphotic surface ocean is a transient buffer in the process of oceanatmosphere $\mathrm{CO}_{2}$ equilibrium, a process retarded by the slow mixing of the surface waters with the intermediate and deep ocean. As such, the greatest changes to the $\mathrm{CO}_{2}$ system are occurring in the surface waters. This build up of $\mathrm{CO}_{2}$ is already altering the carbonate chemistry of the oceans and projections on decadal to centennial timescales point to changes in seawater pH (Caldeira and Wickett, 2003; Bellerby et al., 2005; Blackford and Gilbert, 2007) and carbonate species (Orr et al., 2005) that may have ramifications for the success of organisms or whole marine ecosystems (e.g. Raven et al., 2005; Riebesell, 2004; Kleypas et al., 2006).

Exposure of phytoplankton to $\mathrm{pH}$ and $\mathrm{CO}_{2}$ levels relevant to those anticipated over the coming decades leads to modifications in physiological or morphological properties which may have consequences for ecological structure and biogeochemical cycling. The general assertion is that increasing $\mathrm{CO}_{2}$ has deleterious effects on the growth and productivity of marine calcifiers (e.g. Riebesell et al., 2000; Delille et al., 2005; Orr et al., 2005), although there are notable exceptions (Langer et al., 2006). Overconsumption of carbon, a common response to nutrient and environmental stress is magnified under high $\mathrm{CO}_{2}$ conditions (Zondervan et al., 2002; Engel et al., 2005). Changing $\mathrm{CO}_{2}$ concentrations in aquatic systems has been shown to influence phytoplankton species

Published by Copernicus Publications on behalf of the European Geosciences Union. 
succession (Tortell et al., 2002). Changes to the nutritional quality (higher $\mathrm{C}: \mathrm{P}$ ), in response to increased $\mathrm{CO}_{2}$, of phytoplankton as a food source results in lower growth rate and fecundity in zooplankton (Urabe et al., 2003)

Efforts to understand potential consequences and feedbacks of increasing $\mathrm{CO}_{2}$ have employed laboratory and mesocosm studies either at the individual species level or on natural and perturbed ecosystems (Riebesell et al., 2000; Delille et al., 2005). In this study, a natural ecosystem was perturbed with nutrients over a range of atmospheric $\mathrm{CO}_{2}$ scenarios extending previous studies to include the effects of very high $\mathrm{CO}_{2}$ concentrations postulated for the 22 nd century.

\section{Methods}

\subsection{Experimental}

A mesocosm experiment was performed between 15 May and 9 June 2005 at the University of Bergen Marine Biological station in Raunefjorden, Norway. Nine polyethylene enclosures $\left(\sim 25 \mathrm{~m}^{3}, 9.5 \mathrm{~m}\right.$ water depth) were moored to a raft equipped with a floating laboratory. The enclosures where filled with fjord water from $12 \mathrm{~m}$ depth, and manipulated in order to obtain triplicates of three different $p \mathrm{CO}_{2}$ concentrations $\left(1 \times \mathrm{CO}_{2}(350 \mu \mathrm{atm}), 2 \times \mathrm{CO}_{2}(700 \mu \mathrm{atm})\right.$ and $\left.3 \times \mathrm{CO}_{2}(1050 \mu \mathrm{atm})\right)$. Addition of fresh water to the upper $5.5 \mathrm{~m}$ of the enclosures ensured the generation of a mixed layer separated from the underlying water by a salinity gradient of 1.5. Nitrate and Phosphate were added to the upper mixed layer resulting in initial respective concentrations of 16 and $0.8 \mu \mathrm{mol} \mathrm{kg}^{-1}$. A comprehensive description of the mesocosm setup, $\mathrm{CO}_{2}$ and nutrient perturbation and sampling strategy, as well as the nutrient measurement methodology can be found in Schulz et al. (2008).

Samples for determining the carbon dioxide system were taken from seawater pumped from $1 \mathrm{~m}$ depth in each of the enclosures. The partial pressure of carbon dioxide $\left(p \mathrm{CO}_{2}\right)$ was determined in air equilibrated with seawater $p \mathrm{CO}_{2}$ using an infrared gas analyser (Li-Cor 6262) (Wanninkhof and Thoning, 1993). Gas calibration of the instrument against high quality air standards containing mixing ratios of 345 , 415 and $1100 \mathrm{ppm}$ enveloped the daily seawater measurement program. Following the $p \mathrm{CO}_{2}$ measurements, using the same sampling methodology, samples for total alkalinity $\left(\mathrm{A}_{T}\right)$ and total dissolved inorganic carbon $\left(\mathrm{C}_{T}\right)$ were drawn into $500 \mathrm{ml}$ borate bottles and immediately poisoned with $\mathrm{HgCl}_{2}$. $\mathrm{A}_{T}$ was measured using Gran potentiometric titration (Gran, 1952) on a VINDTA system (Mintrop et al., 2000) with a precision of $\leq 4 \mu \mathrm{mol} \mathrm{kg}-1 . \mathrm{C}_{T}$ was determined using coulometric titration (Johnson et al., 1987) with a precision of $\leq 2 \mu \mathrm{mol} \mathrm{kg}^{-1}$. For both $\mathrm{A}_{T}$ and $\mathrm{C}_{T}$ measurements, samples were filtered through $\mathrm{GF} / \mathrm{F}$ filters placed in the sample inlet tubes to the respective instruments immediately prior to measurement.

\subsection{Calculations}

As the system had settled down by day 2 (16 May), following the initial $\mathrm{CO}_{2}$ and nutrient perturbations (Schulz et al., 2008), all changes to the biogeochemical fields were referenced to this date. Calculation of additional carbon dioxide system variables, from measured $\mathrm{C}_{T}$ and $\mathrm{A}_{T}$ used the CO2SYS program (Lewis and Wallace, 1998) adopting the dissociation constants for carbonic acid (Dickson and Millero, 1987), boric acid (Dickson, 1990a) and sulphuric acid (Dickson, 1990b) and the $\mathrm{CO}_{2}$ solubility coefficient from Weiss (1974). Seawater $\mathrm{pH}$ is reported on the total hydrogen scale.

Particulate inorganic carbon (PIC) production was calculated from temporal changes $(\Delta t)$ in total alkalinity with appropriate correction for alkalinity contributions from net nitrate and phosphate consumption (Goldman and Brewer, 1980):

$\mathrm{PIC}=-0.5 \cdot\left(\frac{\left(\Delta \mathrm{A}_{T}-\Delta\left[\mathrm{NO}_{3}\right]-\Delta\left[\mathrm{PO}_{4}\right]\right)}{\Delta t}\right)$

In order to evaluate biological contributions to the inorganic carbon system it was necessary to first account for the exchange of $\mathrm{CO}_{2}$ between the seawater and the overlying mesocosm atmosphere $\left(\mathrm{CO}_{2(\mathrm{ex})}\right)$. Gas exchange was calculated according to Delille et al. (2005) further employing the chemical enhancement factors of Kuss and Schneider (2004).

Net community production (NCP) was calculated from temporal changes in $\mathrm{C}_{T}$ allowing for modifications due to PIC production or dissolution and net $\mathrm{CO}_{2}$ gas exchange thus:

$\mathrm{NCP}=-\left(\frac{\Delta \mathrm{C}_{T}}{\Delta t}\right)+0.5 \cdot\left(\frac{\left(\Delta \mathrm{A}_{T}-\Delta\left[\mathrm{NO}_{3}\right]-\Delta\left[\mathrm{PO}_{4}\right]\right)}{\Delta t}\right)+\frac{\mathrm{CO}_{2(\mathrm{ex})}}{\Delta t}$

Removal of the contributions of net calcification and air-sea $\mathrm{CO}_{2}$ exchange gives the net perturbation of the inorganic carbon system from community biological activity - the sum of autotrophic and heterotrophic processes within the mixed layer. Comparison of the inferred net organic production and nutrient uptake rates gives the pelagic community molar stoichiometry changes as a response to changing $\mathrm{CO}_{2}$.

\subsection{Statistical analysis}

Statistical analyses were performed on data from all mesocosms. The design of the statistical treatments followed a typical repeated measurement scheme with an outer covariate as the treatment. The response $\left(y_{i j}\right)$ was observed for each particular treatment $\left(\right.$ treat $\left._{i j}\right)$ at time $j=0, \ldots, n_{i}$ within the $i$ 'th mesocosm, $i=1, \ldots, m$. Appropriate to the form of the relationship to be tested both linear and non-linear 

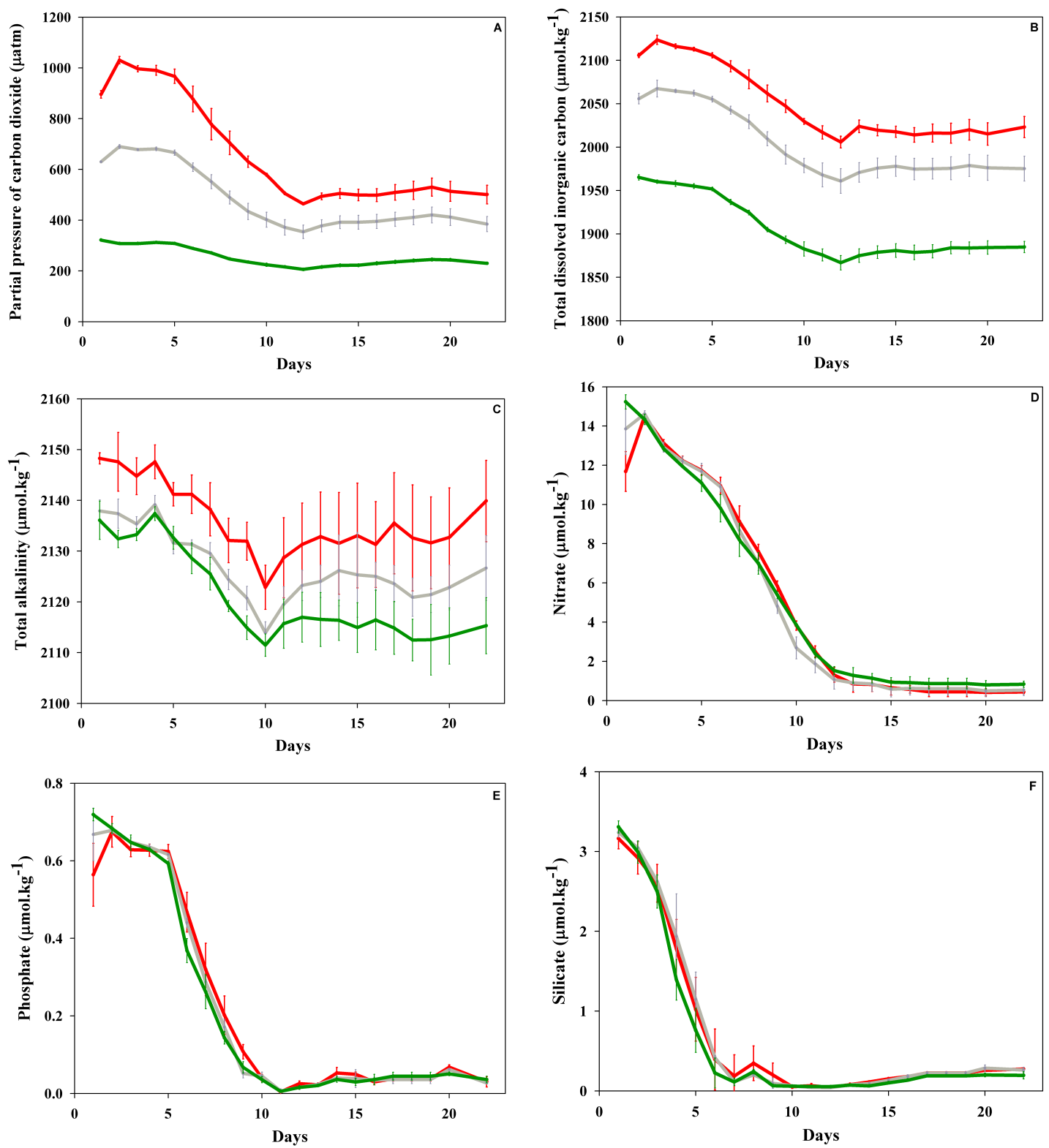

Fig. 1. Temporal development of the carbon dioxide variables and nutrient concentrations within the mesocosm upper mixed layers: (A) partial pressure of carbon dioxide; (B) total dissolved carbon dioxide; (C) Total alkalinity; (D) Nitrate; (E) Phosphate; and (F) Silicate. The mean treatment values (350, 700 and $1050 \mu \mathrm{atm})$, with standard deviation, are represented by the green, grey and red lines, respectively.

mixed models were applied to the treatment data (Pinheiro and Bates, 2000).

\subsubsection{Logistic mixed effect model (L-NLME)}

The logistic relationship was estimated using the self-starting algorithm of SSlogis of the R-library nlme (Pinheiro and Bates, 2000). This relationship was applied for both NCP and PIC as response variable $\left(y_{i j}\right)$ against corresponding day.
The logistic relationship follows:

$y_{i j}=\frac{\phi_{1 i}}{1+\exp \left[-\left(\mathrm{day}_{i j}-\phi_{2 i}\right) / \phi_{3 i}\right]}+\varepsilon_{i j}$

Where $\phi_{1 i}$ is the asymptote, $\phi_{2 i}$ is the xmid and $\phi_{3 i}$ is the scale. The residual component followed a normal distribution, $\varepsilon_{i j} \sim N\left(0, \sigma^{2}\right)$. The mixed effect element is included in the parameter $\phi_{i}=\beta+b_{i}$ where $b_{i}$ is the cluster-specific random effect, $b_{i} \sim N(0, \Psi)$, and $\beta$ is the fixed effect. The treatment effects are included through $\phi_{i}=\beta+\gamma x_{i}+b_{i}$, where $x_{i}$ is the contrast matrix corresponding to the factorial treatment vector. 

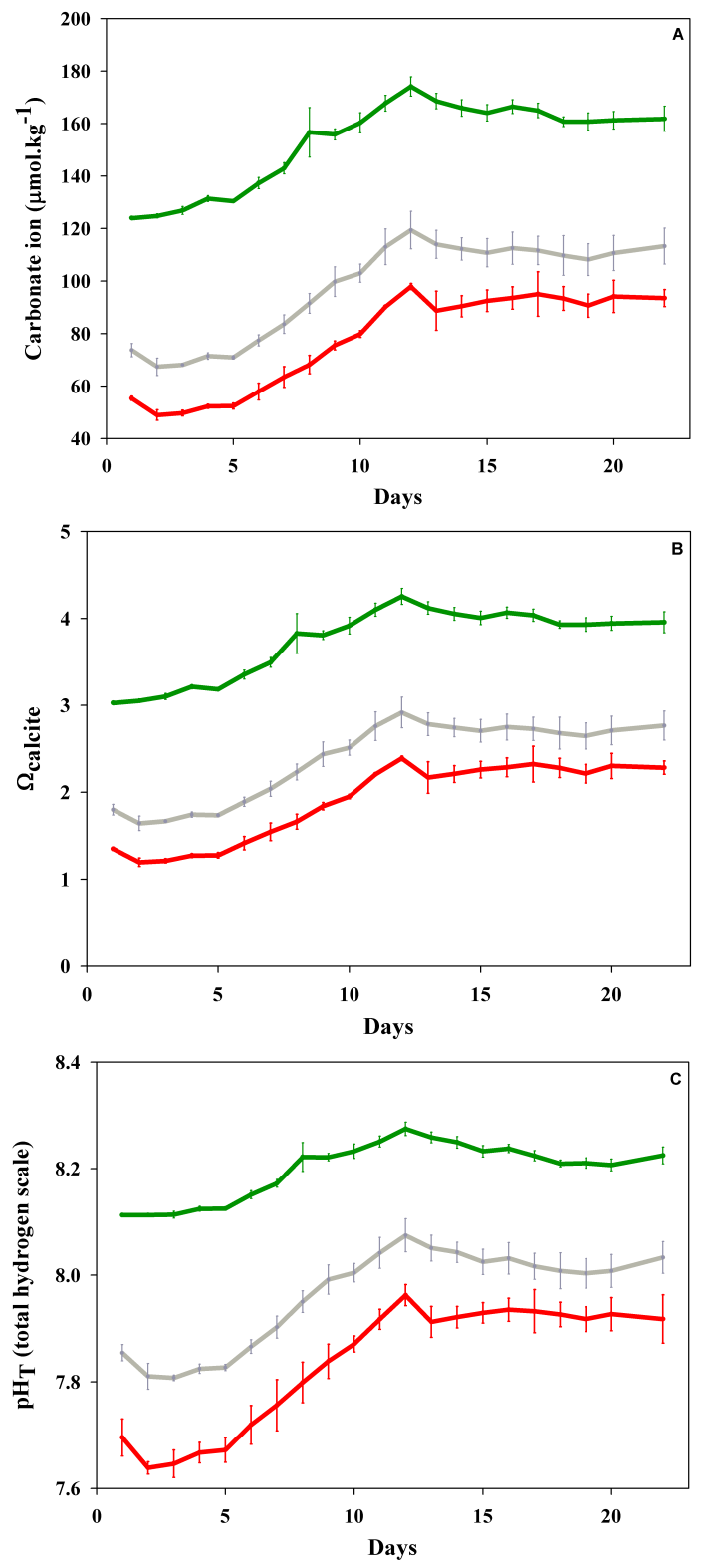

Fig. 2. Calculated carbon dioxide system variables within the mesocosm upper mixed layers: (A) Carbonate ion concentration; (B) saturation state of calcite $(\Omega)$; and $(\mathbf{C}) \mathrm{pH}_{T}$. The colour assignment of treatment is as in Fig. 1.

\subsubsection{Asymptotic mixed effect model (A-NLME)}

An asymptotic relationship was assumed when a sigmoidal relationship were inappropriate. The self-starting algorithm SSasymp (Pinheiro and Bates, 2000) was used for the relationship of $d \mathrm{PO}_{4}$, as response $\left(y_{i j}\right)$, against $\mathrm{NCP}$, following the relationship:

$y_{i j}=\phi_{1 i}+\left(\phi_{2 i}-\phi_{1 i}\right) \exp \left[-\exp \left(\phi_{3 i}\right) \mathrm{NCP}_{i j}\right]$
Where $\phi_{1}$ is the asymptote, $\phi_{2}$ is the intercept and $\phi_{3}$ is the logarithm of the rate constant.

\subsubsection{Linear mixed model (LME)}

For the relationship between $d \mathrm{NO}_{3}$ as the response $\left(y_{i j}\right)$ against $\mathrm{NCP}$ as predictor it was sufficient with a linear mixed effect model (Pinheiro and Bates, 2000):

$$
\begin{aligned}
y_{i j}=\beta_{0} & +b_{0 i}+\beta_{i} \mathrm{NCP}_{i j}+\beta_{2} \text { treat }_{1, i, j}+\beta_{3} \text { treat }_{2, i j} \\
& +\beta_{4} \mathrm{NCP}_{i j} \text { treat }_{1, i j}+\beta_{5} \mathrm{NCP}_{i j} \text { treat }_{2, i j}+\varepsilon_{i j}
\end{aligned}
$$

\section{Results}

\subsection{Temporal evolution of the carbon dioxide system}

In accordance with the agreement for the PeECE special issue, only treatment means are represented in this study except the statistical analyses which were performed on the data from individual mesocosm enclosures. Daily treatment means, with standard deviations, of seawater $p \mathrm{CO}_{2}, \mathrm{C}_{T}$ and nutrient concentrations for the mixed layers in the three perturbation scenarios are shown in Fig. 1.

Once the scenario $\mathrm{CO}_{2}$ concentrations had been reached in the seawater, only the atmospheric concentrations over the water were maintained at the prescribed treatment level and the seawater $\mathrm{CO}_{2}$ system was allowed to respond as in a naturally occurring plankton bloom. There is a clear treatment dependant response in $p \mathrm{CO}_{2}$ (Fig. 1a). Under the $1 \times \mathrm{CO}_{2}$ scenario, $p \mathrm{CO}_{2}$ dropped by $102 \mu \mathrm{atm}$ by the end of the bloom stage (Day 12), whilst $p \mathrm{CO}_{2}$ reductions were 335 and $570 \mu \mathrm{atm}$ in the $2 \times$ and $3 \times \mathrm{CO}_{2}$ scenarios, respectively. Similarly, the $\mathrm{C}_{T}$ reductions also show the same order of response (Fig. 1b). Under the $1 \times \mathrm{CO}_{2}$ treatment, $\mathrm{C}_{T}$ showed a reduction of $94 \mu \mathrm{mol} \mathrm{kg}^{-1}$, increasing to $107 \mu \mathrm{mol} \mathrm{kg}-1$ for $2 \times \mathrm{CO}_{2}$ and to $118 \mu \mathrm{mol} \mathrm{kg}^{-1}$ for $3 \times \mathrm{CO}_{2}$. Initial concentrations of $\mathrm{A}_{T}$ (Fig. 1c) were higher in the $3 \times \mathrm{CO}_{2}$ treatment corresponding with the higher initial salinity (Schulz et al., 2008). Changes in $A_{T}$ throughout the bloom stage indicated a modest treatment response before Day 10 with reductions in $\mathrm{A}_{T}$ of $21,23.5$ and $24.8 \mu \mathrm{mol} \mathrm{kg}^{-1}\left(1 \times \mathrm{CO}_{2}\right.$ through $3 \times \mathrm{CO}_{2}$ treatments). Total alkalinity increased after the bloom peak in the $2 \times$ and $3 \times \mathrm{CO}_{2}$ treatments but remained constant in the $1 \times \mathrm{CO}_{2}$ treatment.

The absolute change in carbonate ion $\left[\mathrm{CO}_{3}^{2-}\right]$ concentrations, on the other hand, showed no treatment dependence and increased by 50,52 and $49 \mu \mathrm{mol} \mathrm{kg}^{-1}$ in the low to high treatments, respectively (Fig. 2a). Correspondingly, as $\Omega$ (the saturation state of calcium carbonate) is controlled mainly by $\left[\mathrm{CO}_{3}^{2-}\right]$, there were similarly increases in the calcite saturation state; $1.2,1.27$ and 1.19 (Fig. 2b). Seawater $\mathrm{pH}\left(\mathrm{pH}_{T}\right)$ values, however, increased the most in the $3 \times \mathrm{CO}_{2}$ treatment from 7.64 to $7.96(\Delta \mathrm{pH}=0.32)$; under the $2 \times \mathrm{CO}_{2}$ scenario the $\mathrm{pH}$ increased from 7.81 to $8.07(\Delta \mathrm{pH}=0.26)$ and in the $1 \times \mathrm{CO}_{2}$ treatment from 8.11 to $8.27(\Delta \mathrm{pH}=0.16)$. 

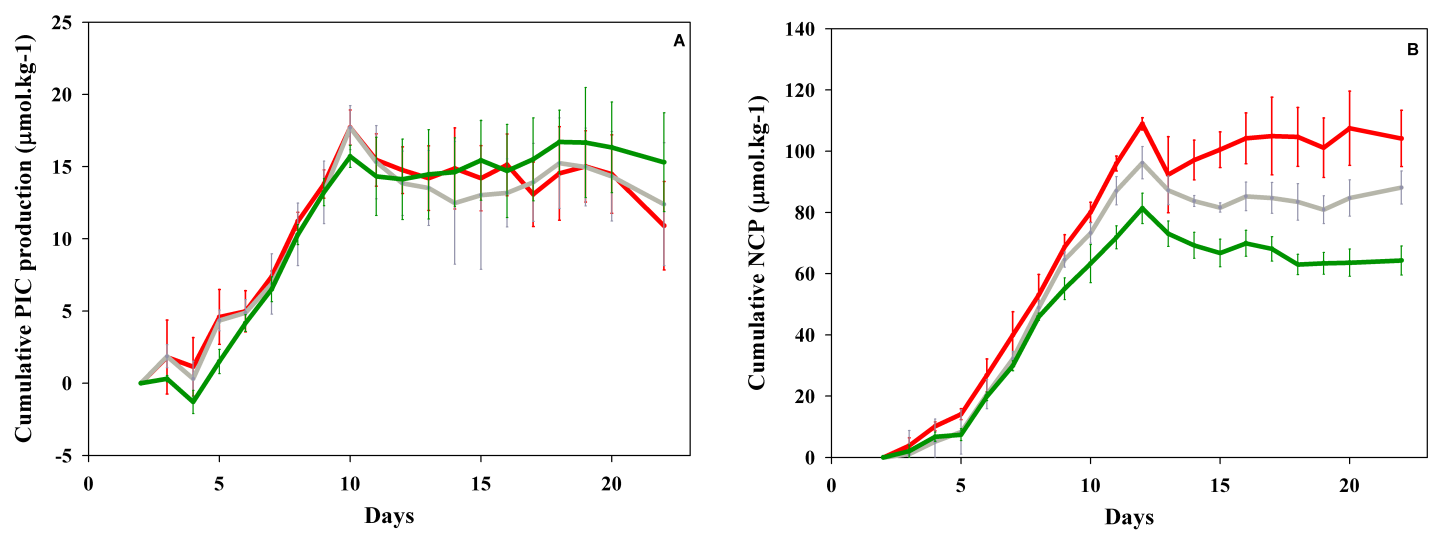

Fig. 3. The main contributors to changes in the inorganic carbon concentration throughout the experiment (A) Cumulative particulate inorganic carbon (PIC) production and (B) net community production (NCP). The contribution of $\mathrm{CO}_{2}$ air-sea gas exchange to the net $\mathrm{CT}$ change was small $(<1 \%)$ and not shown. The colour assignment of treatment is as in Fig. 1.

There was no significant difference in particulate inorganic carbon (PIC) production between $\mathrm{CO}_{2}$ treatments (L-NLME, $p=0.77, n=170$ ) (Fig. 3a). The dominant calcifier in the bloom was the prymesiophyte Emiliania Huxleyi (Paulino et al., 2008) and PIC production increased to a maximum of $15 \mu \mathrm{mol} \mathrm{kg}{ }^{-1}$ on Day 10 corresponding to the start of the demise of the Emiliania Huxleyi population (Paulino et al., 2008).

Net community production (NCP) (Fig. 3b), the net organic carbon production, contributed the most to the changes in inorganic carbon dioxide shown in Fig. $1 \mathrm{~b}$ with contributions to the $\mathrm{C}_{T}$ changes from PIC and air-sea $\mathrm{CO}_{2}$ exchange (not shown) of only 15-20\%. The cumulative NCP has a maximum on Day 12 and shows a clear treatment response with maximum production, relative to Day 2 (LNLME, $p<0.001, n=170$ ). The $3 \times \mathrm{CO}_{2}$ treatment produced $110 \mu \mathrm{mol} \mathrm{kg}^{-1}$, falling to $96 \mu \mathrm{mol} \mathrm{kg}^{-1}$ and $80 \mu \mathrm{mol} \mathrm{kg}-1$ in the $2 \times \mathrm{CO}_{2}$ and $1 \times \mathrm{CO}_{2}$ treatments. After Day 12 there is a fall in calculated NCP with further treatment divergence in NCP until the end of the experiment - again favouring the $3 \times \mathrm{CO}_{2}$ treatment.

\subsection{Temporal evolution of nutrients}

The treatment dependant changes in the major nutrients nitrate, phosphate and silicate are shown in Fig. 1c-e. Both nutrient uptake and the timing of nutrient minima showed no dependency on $\mathrm{CO}_{2}$ treatment although there were intertreatment variations in the planktonic assemblages (Paulino et al., 2008). Silicate was not added during the experimental set-up, however a residual concentration of about $3 \mu \mathrm{mol} \mathrm{kg}{ }^{-1}$ was inherited from the fjord water used to fill the mesocosm enclosures. Silicate concentrations dropped sharply due to diatom uptake and reached a minimum on day 9-10. Phosphate concentrations showed only modest reductions until day 5 after which rapid uptake led to a minimum on day 11. From the onset of the experiment, concentrations of nitrate diminished at a steady rate until Day 12 then declined slowly until the end of the experiment.

The stoichiometry of net community inorganic nutrient to calculated organic carbon uptake is shown in Fig. 4. As expected, with the measured nutrient concentrations exhibiting no scenario dependence, there is little deviation in nutrient stoichiometry between treatments. In the pre-bloom period, until day 5, there is a greater uptake of nitrate to phosphate relative to the Redfield ratio (16:1) (Redfield et al., 1963). In the initial stage of the bloom, relative phosphate uptake increases rapidly on Day 6. Thereafter, the system behaves very close to Redfieldian until the end of the bloom when N:P rose slowly to a final cumulative value of 21 in all treatments.

Nitrate uptake is high compared to silicate uptake until Day 4, after which the diatom bloom started (Paulino et al., 2008) and silicate was consumed at about 1:1 with nitrate until silicate reached a first minimum on Day 7. There followed a small peak in silicate concentration on Day 8 (Fig. 1f) after which silicate became depleted on Day 9-10.

In contrast to the nutrient stoichiometric ratios, there are significant treatment dependant differences between the carbon to nitrate (C:N) (LME, $p<0.001, n=170)$ (Fig. 4c, g) and carbon to phosphate (C:P) ratios (A-NLME, $p<0.001$, $n=170$ ) (Fig. 4d, h). Overconsumption of carbon results in a higher $\mathrm{C}: \mathrm{N}$ uptake ratio under higher $\mathrm{CO}_{2}$ exposures. Cumulative $\mathrm{C}: \mathrm{N}$ uptake was higher in the $3 \times \mathrm{CO}_{2}$ scenario throughout the entire bloom, quickly reaching a peak of 7.58.25 by Day 6 and remaining at this level until Day 12 . The pre-bloom responses in the $1 \times$ and $2 \times \mathrm{CO}_{2}$ treatments were similar until day 5 after which the $2 \times \mathrm{CO}_{2}$ treatment increased C:N uptake to 7.1. A similar order of response was seen in the $C: P$ ratio with the $3 \times$ treatment showing a greater carbon overconsumption throughout the experiment. By the height of the bloom, the cumulative C:N:P stoichiometry of 

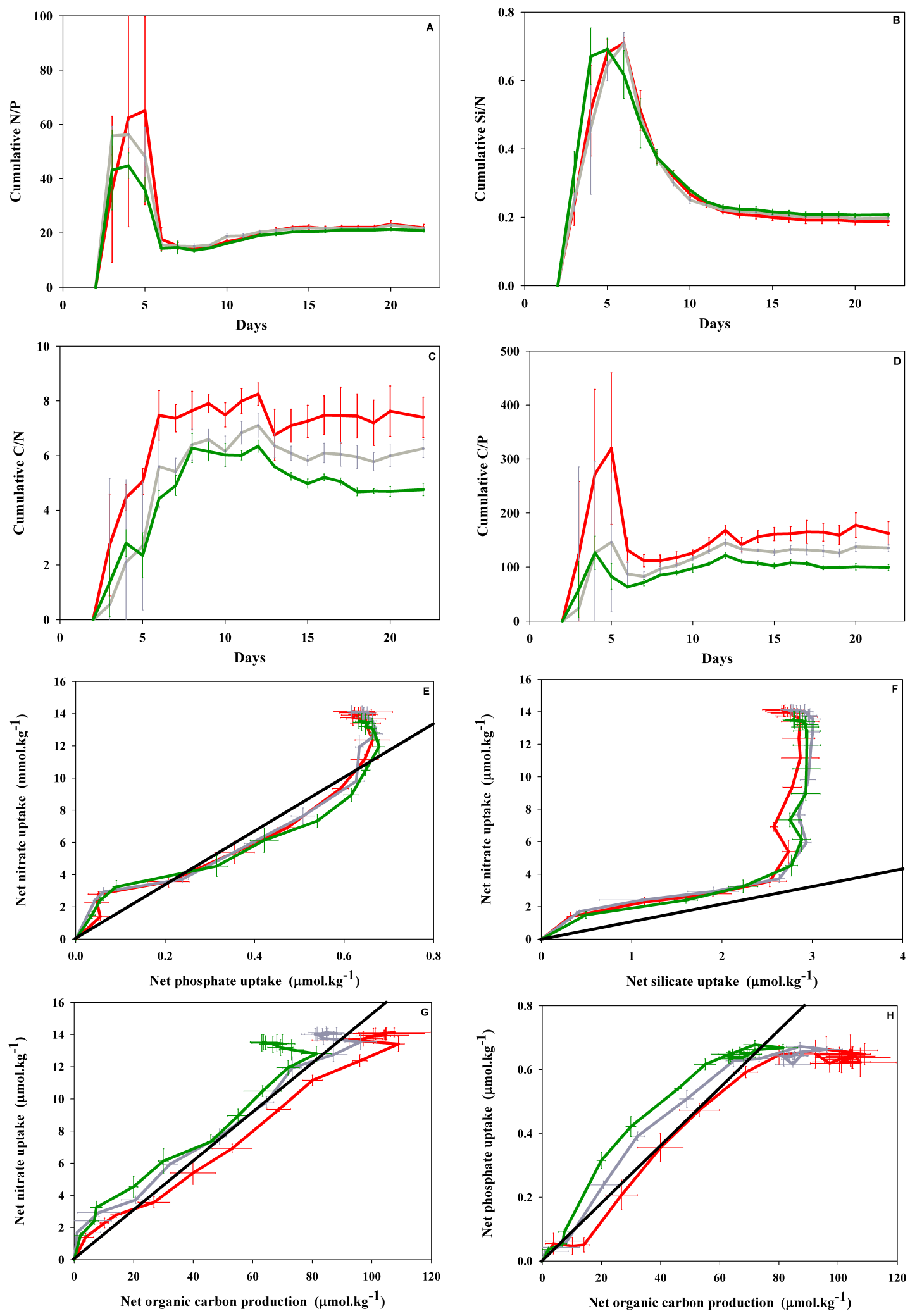

Fig. 4. Net community nutrient stoichiometric uptake ratios referenced to Day 2. Illustrated are the respective daily changes and parameterparameter relationships for nitrate to phosphate $(\mathbf{A}, \mathbf{E})$; silicate to nitrate $(\mathbf{B}, \mathbf{F})$; organic carbon to nitrate $(\mathbf{C}, \mathbf{G})$; and organic carbon to phosphate (D, H). The black line represents the conventional Redfield ratio (Redfield et al., 1963) (E, G, H)) and a silicate-nitrate relationship of 0.95:1 from the mean of diatom species Si/N reported in Table 3 of Brezinski (1985) $(0.95: 1 \pm 0.4)(\mathrm{F})$. The colour assignment of treatment is as in Fig. 1. 
net organic production increased with $\mathrm{CO}_{2}$ treatment from $1: 6.3: 121$ to $1: 7.1: 144$ to $1: 8.25: 168$. In contrast to the $\mathrm{C}: \mathrm{N}$ response, the C:P increased significantly in the post-bloom phase.

\section{Discussion}

\subsection{Modification of the carbonate system}

As changes to $\mathrm{A}_{T}$ (including contributions from nutrient alkalinity) were similar and low and gas exchange minimal in all treatments, modifications to $\mathrm{C}_{T}$ were mainly due to organic carbon production. As such, the greatest changes were related to the treatment dependant carbon overconsumption with increasing uptake with increasing initial $p \mathrm{CO}_{2}$. The effect on $p \mathrm{CO}_{2}$ due to the greater carbon uptake is exacerbated due to the low buffer capacity of the high $\mathrm{CO}_{2}$ seawater resulting in a rapid reduction of $p \mathrm{CO}_{2}$ in the $3 \times \mathrm{CO}_{2}$ treatment. The opposite response is seen with $\mathrm{pH}_{T}$ with the largest increases found in the $3 \times \mathrm{CO}_{2}$ scenario. Due to the weakly buffered system in a future ocean, pelagic ecosystems will undergo greater seasonal changes in their ambient $\mathrm{CO}_{2}$ fields. Increasing $\mathrm{CO}_{2}$ will reach a point where changes to the carbonate system will move outside the contemporary "carbonate system envelope" and accordingly, in this experiment, at no point did any of the calculated carbonate system variables in the future $2 \times \mathrm{CO}_{2}$ and $3 \times \mathrm{CO}_{2}$ scenarios overlap with the range of the contemporary $1 \times \mathrm{CO}_{2}$ scenario.

\subsection{Calcification}

The growth and health of many calcifying marine organisms have been shown to respond to the saturation state of $\mathrm{CaCO}_{3}$ $\left(\Omega_{\text {calcite}}\right)$ in seawater (e.g. Gattuso et al., 1998; Riebesell et al., 2000; Langdon et al., 2003; Kleypas et al., 2006; Delille et al., 2005; Langer et al., 2006). The dominant calcifier during the experiment was the prymesiophyte Emiliania Huxleyi which is common to the Norwegian fjords and open waters of the Norwegian and Barents Sea. Calcification in Emiliania Huxleyi has been shown to be controlled by light, nutrient (especially phosphate) and carbonate ion concentrations and calcite saturation state (see review in Zondervan, 2007). The photon flux density (PFD) concentrations throughout the experiment (Schulz et al., 2008) always exceeded the threshold for saturation of $150-300 \mu$ mol photons $\mathrm{m}^{-2} \mathrm{~s}^{-1}$ found by Nielsen (1997) and Zondervan et al. (2002) and therefore it is assumed that there was no light limitation on calcification. In this study there was no treatment difference in nutrient utilisation although the concentrations of Emiliania Huxleyi varied between treatments (Paulino et al., 2008). Merico et al. (2006) postulated that the seawater carbonate ion concentration could be a control on the onset of calcification and Delille et al. (2005) showed that calcification was delayed by 1 day during a $2 \times \mathrm{CO}_{2}$ treatment compared to the contemporary treatment. This study does not find any relationship between $\left[\mathrm{CO}_{3}^{2-}\right]$ and the timing or degree of calcification. Further, although the $\left[\mathrm{CO}_{3}^{2-}\right]$ and $\Omega_{\text {calcite values }}$ showed marked inter-treatment variations throughout the experiment there was no difference in cumulative net community calcification by the peak of the bloom as also identified by Schulz et al. (2008) using direct measurements of PIC. This finding varies from the results of Delille et al. (2005) who reported a $40 \%$ reduction in PIC production between $1 \times \mathrm{CO}_{2}$ and $2 \times \mathrm{CO}_{2}$ treatments. Conversely, this study does not show the promotion of higher calcification with increasing $\mathrm{CO}_{2}$ as found by Langer et al. (2006).

The peak concentrations of Emiliania Huxleyi in this study were $4-6 \times 10^{6}$ cells L ${ }^{-1}$ (Paulino et al., 2008) which is representative of the concentrations found in the North Atlantic and Norwegian Sea (Tyrrell and Merico, 2004). The Delille et al. (2005) experiment had much higher concentrations (4$6 \times 10^{7}$ cells $\mathrm{L}^{-1}$ ) more representative of the intense blooms found in the Norwegian Fjords (Tyrrell and Merico, 2004). Extrapolating the Delille et al. (2005) calcification response to the PeECE III study cell numbers translates to a predicted reduction in PIC production of $6 \mu \mathrm{mol} \mathrm{kg}^{-1}\left(1 \times \mathrm{CO}_{2-}\right.$ $2 \times \mathrm{CO}_{2}$ treatment). This corresponds to a change in carbonate alkalinity of $12 \mu \mathrm{mol} \mathrm{kg}^{-1}$ well within the measurement precision of the current methodology. A closer look at Emiliania Huxleyii concentrations reveals that there was an increase in cell numbers (Paulino et al., 2008), perhaps facilitated through lower virus (EhV) concentration (Larsen et al., 2008), with increasing $\mathrm{CO}_{2}$. Therefore, the cells in the higher $\mathrm{CO}_{2}$ treatments may have been healthier and thus able to calcify more efficiently. A further artefact of the experimental design was the lack of deep water total alkalinity measurements. The small salinity changes throughout the experiment (Schulz et al., 2008) suggest a potential input of $A_{T}$ from below the pycnocline which are accounted for in the inverse method.

\subsection{Carbon consumption and nutrient stoichiometry}

Elemental stoichiometry of biological production in the surface ocean controls, to a great extent, nutrient balance and cycling of the global ocean. Ocean nutrient stoichiometry is controlled on short timescales by the resource allocation in marine organisms (e.g. Redfield et al., 1963; Klausmeier et al., 2004) and on longer scales by continental nutrient supply (Broecker, 1982). The degree of biogeochemical connectivity between the surface and the interior ocean is also controlled by the rate and stoichiometry of sedimenting material. In this work, molar stoichiometric nutrient uptake ratios are inferred from the uptake of dissolved inorganic nutrients and thus reflect the community balance at a particular time. This method, therefore, cannot discriminate species specific uptake as suggested by Klausmeier et al. (2004) but may be used to characterise distinct patterns in community nutrient balance under differing $\mathrm{CO}_{2}$ regimes. 
Overconsumption of carbon relative to nutrient supply has been reported in several studies of the planktonic response to increased $\mathrm{CO}_{2}$ (Riebesell et al., 1993, 2000; Banse, 1994; Delille at al., 2005; Engel et al., 2005). The increase in carbon uptake is usually seen at the end of the bloom from TEP production in response to nutrient stress (Engel, 2002; Engel et al., 2004). Hein and Sand-Jensen (1997) reported an immediate $(2 \mathrm{~h})$ increase in primary production in relation to increased $\mathrm{CO}_{2}$ concentrations. Changes in dissolved aqueous $\mathrm{CO}_{2}$ may determine the phytoplankton cell size distribution (Engel et al., 2008). Egge et al. (2007) also reported increased primary production, based on in situ ${ }^{14} \mathrm{C}$ incubations, in this study in the higher $\mathrm{CO}_{2}$ treatments towards the peak of the bloom. However, the overconsumption derived from chemical uptake estimations is seen from the onset of the experiment and is proportional to the initial treatment $\mathrm{CO}_{2}$ concentration (see also Riebesell et al., 2007). Schulz et al. (2008) report no changes to the stoichiometry of dissolved and particulate organic matter. This apparent contradiction may be due to an increase in the carbon exported from the mixed layer relative to nutrient concentration in the high $\mathrm{CO}_{2}$ treatments. Allgaier et al. (2008) state that the apparent increase in DOC production did not stimulate bacterial secondary production due to $\mathrm{N}$ and $\mathrm{P}$ limitation reported by Tanaka et al. (2008) and that TEP production, DOC exudation and ensuing enhanced sedimentation must have been high. The products and processes of export production were poorly sampled in the waters below the pycnocline and thus no concrete explanation is possible of the fate of the missing organic carbon. Schulz et al. (2008) suggest from ammonium measurements that there must have been significant remineralisation in the lower $1.5 \mathrm{~m}$ of the mesocosms, especially in the high $\mathrm{CO}_{2}$ treatments fuelled by increased carbon export. The role of benthic organisms living on the walls of the mesocosm enclosures, which has been shown to impact biogeochemical cycling during mesocosm studies (Chen et al., 1997; Berg et al., 1999; Petersen et al., 1999), was not studied.

4.4 Consequences for ecosystem functioning, ocean biogeochemical cycling and atmospheric $\mathrm{CO}_{2}$ control

The elemental stoichiometry of biological export has an important role in controlling atmospheric $\mathrm{CO}_{2}$ concentrations (Broecker, 1982; Volk and Hoffart, 1985; Omta et al., 2006). From first principles, the stoichiometry of osmotroph uptake is transferred to the standing stock of pelagic production. Non-Redfield signatures of biological production have been documented in the surface ocean (Sambrotto et al., 1993; Anderson and Sarmiento, 1994; Falck and Anderson, 2005; Koeve, 2006) and at depth (Körtzinger et al., 2001; Pahlow and Riebesell, 2000). This study has indicated an increase in the carbon:nutrient stoichiometry of pelagic osmotroph productivity in a high $\mathrm{CO}_{2}$ world. If the PeECE results are representative of global productivity, with an ef- ficient transfer of this carbon overconsumption to depth, the increase in atmospheric $\mathrm{CO}_{2}$ proposed by the end of the century may be reduced by $58 \mu \mathrm{atm}$ (Riebesell et al., 2007). The efficiency of carbon-nutrient perturbations in the upper ocean on atmospheric $\mathrm{CO}_{2}$ depends on the rate and ultimate depth of sedimentation which has been shown to be significantly controlled by the ballast of the sedimenting material (Klaas and Archer, 2002). The ballast is mainly dependant on the proportion of $\mathrm{CaCO}_{3}$ to particulate organic carbon $\left(\mathrm{CaCO}_{3}: \mathrm{POC}\right)$ and has been used to test the sensitivity of changes to the carbonate pump on atmospheric $\mathrm{CO}_{2}$ (Heinze, 2004; Ridgwell et al., 2007). Previous studies have identified a reduction in the calcification rate of pelagic calcifiers (summarised in Ridgwell et al., 2007). Calcification was insensitive to $\mathrm{CO}_{2}$ level in this study and Schulz et al. (2008) show that there was increased export of organic carbon from the mixed layer under the $3 \times \mathrm{CO}_{2}$ treatment, suggesting a lowering of the ballast effect. This would suggest that the atmospheric control proposed by Riebesell et al. (2007) would be diminished if there were no compensatory processes to offset the reductions in the ballast effect. However, Engel et al. (2008) show that there was an increase in the cell size during the PeECE II experiment. This cell size change with increases in TEP production and, thus potentially higher aggregation of particulates shown to be a response of similar pelagic plankton communities (Engel, 2002; Engel et al., 2004), may be a mechanism to increase sedimentation rates in a high $\mathrm{CO}_{2}$ environments.

Carbon overconsumption by osmotrophs changes the nutritional quality of food for zooplankton. Lower growth, productivity and fecundity has been documented in zooplankton fed on phytoplankton grown under high $\mathrm{CO}_{2}$ (Sterner and Elser, 2002; Urabe et al., 2003,; Anderson et al., 2005). Carotenuto et al. (2007) hypothesise that the high C:N uptake during the PeECE III study reduced recruitment of zooplankton nauplii. Changes to the ecological structure of pelagic community will also control the export of stoichiometric signals through changes to the size structure and ballast of sedimenting material.

There exists now a large array of experimental data, from laboratory and mesocosm studies of individual species and ecosystem studies, on ecological and biogeochemical responses to ocean acidification. The requirement now is for detailed statistical metaanalysis to breakdown the complexity and often contradiction of experimental results, to identify the dominant controls and responses to ocean acidification. With this information, the observationalists and modellers, presently identifying large contemporary changes in the oceanic carbon sinks (e.g. Schuster and Watson, 2007; Canadell et al., 2007), will be able to focus efforts on the oceanic processes sensitive to changes in the $\mathrm{CO}_{2}$ system.

Acknowledgements. The staff at the Marine Biological Station, University of Bergen, in particular Tomas Sørlie and Agnes Aadnesen, and the Bergen Marine Research infrastructure (RI) 
are gratefully acknowledged for support in mesocosm logistics. This work was partially funded through the EU project CARBOOCEAN "Marine carbon sources and sinks assessment" (contract no. 511176), the Norwegian Research Council projects CABANERA "Carbon flux and ecosystem feedback in the northern Barents Sea in an era of climate change" (contract no. 155936/700) and MERCLIM "Marine Ecosystem Response to a Changing Climate" (contract no. 184860/S30) and the University of Bergen LOCUS project. This is publication number A181 of the Bjerknes Centre for Climate Research.

Edited by: M. Dai

\section{References}

Allgaier, M., Riebesell, U., Vogt, M., Thyrhaug, R., and Grossart, H.-P.: Coupling of heterotrophic bacteria to phytoplankton bloom development at different $p \mathrm{CO}_{2}$ levels: a mesocosm study, Biogeosciences, 5, 1007-1022, 2008, http://www.biogeosciences.net/5/1007/2008/.

Anderson, L. and Sarmiento, J.: Redfield ratios of remineralization determined by nutrient data analysis, Global Biogeochem. Cy., 8, 65-80, 1994.

Anderson, T. R., Hessen, D. O., Elser, J. J., and Urabe, J.: Metabolic stoichiometry and the fate of excess carbon and nutrients in consumers, Am. Nat., 165(1), 1-11, 2005.

Banse, K.: Uptake of inorganic carbon and nitrate by marine plankton and the Redfield ratio, Global Biogeochem. Cy., 8, 81-84, 1994.

Bellerby, R. G. J., Olsen, A., Furevik, T., and Anderson, L. A.: Response of the surface ocean $\mathrm{CO}_{2}$ system in the Nordic Seas and North Atlantic to climate change, in: Climate Variability in the Nordic Seas, edited by: Drange, H., Dokken, T. M., Furevik, T., Gerdes, R., and Berger, W., Geophysical Monograph Series, AGU, 189-198, 2005.

Berg, G. M., Glibert, P. M., and Chen, C,-C.: Dimension effects of enclosures on ecological processes in pelagic systems, Limnol. Oceanogr., 44(5), 1331-1340, 1999.

Blackford, J. C. and Gilbert, F. J.: $\mathrm{pH}$ variability and $\mathrm{CO}_{2}$ induced acidification in the North Sea, J. Marine Syst., 1-4, 229-241, 2007.

Brezinski, M.: The Si:C:N ratio of marine diatoms: interspecific variability and the effect of some environmental variables, J. Phycol., 21, 347-357, 1985.

Broecker, W. S.: Ocean geochemistry during glacial time, Geochimica Cosmochimica Acta, 46, 1689-1705, 1982.

Caldeira, K. and Wickett, M. E.: Anthropogenic carbon and ocean pH, Nature, 425, 365-365, 2003.

Canadell, J. G., Le Quéré, C., Raupach, M. R., Field, C. B., Buitenhuis, E. T., Ciais, P., Conway, T. J., Gillett, N. P., Houghton, R. A., and Marland, G.: Contributions to accelerating atmospheric $\mathrm{CO}_{2}$ growth from economic activity, carbon intensity, and efficiency of natural sinks, Proceedings of the National Academy of Science, USA, doi:10.1073/pnas.0702737104, 2007.

Carotenuto, Y., Putzeys, S., Simonelli, P., Paulino, A., Meyerhöfer, M., Suffrian, K., Antia, A., and Nejstgaard, J. C.: Copepod feeding and reproduction in relation to phytoplankton development during the PeECE III mesocosm experiment, Biogeosciences
Discuss., 4, 3913-3936, 2007,

http://www.biogeosciences-discuss.net/4/3913/2007/.

Chen, C.-C., Petersen, J. E., and Kemp, W. M.: Spatial and temporal scaling of periphyton growth on walls of estuarine mesocosms, Mar. Ecol.-Prog. Ser., 155, 1-15, 1997.

Delille, B., Harlay, J., Zondervan, I., Jacquet, S., Chou, L., Wollast, R., Bellerby, R. G. J., Frankignoulle, M., Borges, A. V., Riebesell, U., and Gattuso, J.-P.: Response of primary production and calcification to changes of $\mathrm{pCO}_{2}$ during experimental blooms of the coccolithophorid Emiliania huxleyi, Global Biogeochem. Cy., 19, GB2023, doi:10.1029/2004GB002318, 2005.

Dickson, A. G.: Standard potential of the reaction: $\mathrm{AgCl}(\mathrm{s})+1 / 2$ $\mathrm{H}_{2}(\mathrm{~g})=\mathrm{Ag}(\mathrm{s})+\mathrm{HCl}(\mathrm{aq})$, and the standard acidity constant of the ion $\mathrm{HSO}_{4}^{-}$in synthetic seawater from 273.15 to $318.15 \mathrm{~K}$, J. Chem. Thermodyn., 22, 113-127, 1990a.

Dickson, A. G.: Thermodynamics of the dissociation of boric acid in synthetic sea water from 273.15 to 318.15 K, Deep-Sea Res., 37, 755-766, 1990b.

Dickson, A. G. and Millero, F. J.: A comparison of the equilibrium constants for the dissociation of carbonic acid in seawater media, Deep-Sea Res., 34, 1733-1743, 1987.

Egge, J. K., Thingstad, T. F., Engel, A., Bellerby, R. G. J., and Riebesell, U.: Primary production during nutrient-induced blooms at elevated $\mathrm{CO}_{2}$ concentrations, Biogeosciences Discuss., 4, 4385-4410, 2007,

http://www.biogeosciences-discuss.net/4/4385/2007/.

Engel, A.: Direct relationship between $\mathrm{CO}_{2}$ uptake and transparent exopolymer particles production in natural phytoplankton, $\mathrm{J}$. Plankton Res., 24, 49-53, 2002.

Engel, A., Thoms, S., Riebesell, U., Rochelle-Newall, E., and Zondervan, I.: Polysaccharide aggregation as a potenial sink of marine dissolved organic carbon, Nature, 428, 929-932, 2004.

Engel, A., Zondervan, I., Aerts, K., Beaufort, L., Benthien, A., Chou, L., Delille, B., Gattuso, J.-P., Harley, J., Heemann, C., Hoffmann, L., Jacquet, S., Nejstgaard, J., Pizay, M.-D., Rochelle-Newall, E., Schneider, U., Terbrüggen, A., and Riebesell, U.: Testing the direct effect of $\mathrm{CO}_{2}$ concentration on a bloom of the coccolithophorid Emiliania huxleyi in mesocosm experiments, Limnol. Oceanogr., 50, 493-504, 2005.

Engel, A., Schulz, K. G., Riebesell, U., Bellerby, R., Delille, B., and Schartau, M.: Effects of $\mathrm{CO}_{2}$ on particle size distribution and phytoplankton abundance during a mesocosm bloom experiment (PeECE II), Biogeosciences, 5, 509-521, 2008, http://www.biogeosciences.net/5/509/2008/.

Falck, E. and Anderson, L.G.: The dynamics of the carbon cycle in the surface water of the Norwegian Sea, Mar. Chem., 94, 43-53, 2005.

Gattuso, J.-P., Frankignoulle, M., Bourge, I., Romaine, S., and Buddemeier, R. W.: Effect of calcium carbonate saturation of seawater on coral calcification, Global Planet. Change, 18, 37-46, 1998.

Goldman, J. C. and Brewer, P. G.: Effect of nitrogen source and growth rate on phytoplankton-mediated changes in alkalinity, Limnol. Oceanogr., 25(2), 352-357, 1980.

Gran, G.: Determination of the equivalence point in potentiometric titrations of seawater with hydrochloric acid, Oceanologica Acta, 5, 209-218, 1952.

Hein, M. and Sand-Jensen, K.: $\mathrm{CO}_{2}$ Increases Oceanic Primary Production, Nature, 388(6642), 526-527, 1997. 
Heinze, C.: Simulating oceanic $\mathrm{Ca} \mathrm{CO}_{3}$ export production in the greenhouse, Geophys. Res. Lett., 31, L16308, doi:10.1029/2004GL020613, 2004.

Johnson, K. M., Sieburth, J. M., Williams, P. J., and Brändström, L.: Coulometric total carbon analysis for marine studies: automation and calibration, Mar. Chem., 21, 117-133, 1987.

Klaas, C. and Archer, D. E.: Association of sinking organic matter with various types of mineral ballast in the deep sea: Implications for the rain ratio, Global Biogeochem. Cy., 16(4), 1116, doi:10.1029/2001GB001765, 2002.

Klausmeier, C. A., Litchman, E., Daufresne, T., and Levin, S. A.: Optimal nitrogen-to-phosphorus stoichiometry of phytoplankton, Nature, 429, 171-174, 2004.

Kleypas, J. A., Feely, R. A, Fabry, V. J., Langdon, C., Sabine, C. L., and Robbins, L. L.: Impacts of Ocean Acidification on Coral Reefs and Other Marine Calcifiers. A Guide for Future Research, Report of a workshop sponsored by NSF, NOAA and the USGS, 88 pp., 2006.

Koeve, W.: C:N stoichiometry of the biological pump in the North Atlantic: Constraints from climatological data, Global Biogeochem. Cy., 20, GB3018, doi:10.1029/2004GB002407, 2006.

Körtzinger, A., Hedges, J. I., and Quay, P. D.: Redfield ratios revisited: removing the biasing effect of anthropogenic $\mathrm{CO}_{2}$, Limnol. Oceanogr., 46, 964-970, 2001.

Kuss, J. and Schneider, B.: Chemical enhancement of the $\mathrm{CO}_{2}$ gas exchange at a smooth seawater surface, Mar. Chem., 91, 165$174,2004$.

Langdon, C., Broecker, W. S., Hammond, D. E., Glenn, E., Fitzsimmons, K., Nelson, S. G., Peng, T.-S., Hajdas, I., and Bonani, G.: Effect of elevated $\mathrm{CO}_{2}$ on the community metabolism of an experimental coral reef, Global Biogeochem. Cy., 17, 1011, doi:10.1029/2002GB001941, 2003.

Langer, G., Geisen, M., Kläs, J., Riebesell, U., Thoms, S., Young, J. R.: Species-specific responses of calcifying algae to changing seawater carbonate chemistry, Geochem. Geophy. Geosy., 7 (9), Q09006, doi:10.1029/2005GC001227, 2006.

Larsen, J. B., Larsen, A., Thyrhaug, R., Bratbak, G., and Sandaa, R.-A.: Response of marine viral populations to a nutrient induced phytoplankton bloom at different $p \mathrm{CO}_{2}$ levels, Biogeosciences, 5, 523-533, 2008, http://www.biogeosciences.net/5/523/2008/.

Lewis, E. and Wallace, D. W. R.: Program Developed for $\mathrm{CO}_{2}$ System Calculations. ORNL/CDIAC-105. Carbon Dioxide Information Analysis Center, Oak Ridge National Laboratory, U.S. Department of Energy, Oak Ridge, Tennessee, 1998.

Merico, A., Tyrrell, T., and Cocakar, T.: Is there any relationship between phytoplankton seasonal dynamics and the carbonate system?, J. Marine Syst., 59, 120-142, 2006.

Mintrop, L., Fernández-Pérez, F., González Dávila, M., Körtzinger, A., and Santana Casiano, J. M.: Alkalinity determination by potentiometry- intercalibration using three different methods, Ciencias Marinas, 26, 23-37, 2000.

Nielsen, M. V.: Photosynthetic characteristics of the coccolithophorid Emiliania huxleyi (Prymnesiophyceae) exposed to elevated concentrations of dissolved inorganic carbon, J. Phycol., 31, 715-719, 1995.

Omta, A. W., Bruggeman, J., Kooijman, S. A. L. M., and Dijkstra, H. A.: Biological carbon pump revisited: Feedback mechanisms between climate and the Redfield ratio, Geophys. Res. Lett., 33,
L14613, doi:10.1029/2006GL026213, 2006.

Orr, J. C., Fabry, V. J., Aumont, O., Bopp, L., Doney, S. C., Feely, R. A., Gnanadesikan, A., Gruber, N., Ishida, A., Joos, F., Key, R. M., Lindsay, K., Maier-Reimer, E., Matear, R., Monfray, P., Mouchet, A., Najjar, R. G., Plattner, G. K., Rodgers, K. B., Sabine, C. L., Sarmiento, J. L., Schlitzer, R., Slater, R. D., Totterdell, I. J., Weirig, M. F., Yamanaka, Y., and Yool, A.: Anthropogenic ocean acidification over the twenty-first century and its impact on calcifying organisms, Nature, 437, 7059, 681-686, doi:10.1038/nature04095, 2005.

Pahlow, M. and Riebesell, U.: Temporal trends in deep ocean Redfield ratios, Science, 287, 831-833, 2000.

Paulino, A. I., Egge, J. K., and Larsen, A.: Effects of increased atmospheric $\mathrm{CO}_{2}$ on small and intermediate sized osmotrophs during a nutrient induced phytoplankton bloom, Biogeosciences, 5, 739-748, 2008,

http://www.biogeosciences.net/5/739/2008/.

Petersen, J. E., Cornwell, J. C., and Kemp, W. M.: Implicit scaling in the design of experimental aquatic ecosystems, Oikos, 85, 3$18,1999$.

Pinheiro, J. C. and Bates, D. M.: Mixed-Effects Models in S and S-plus, Springer, New York, 527 pp., 2000.

Raven, J., Caldeira, K., Elderfield, H., Hoegh-Guldberg, O., Liss, P., Riebesell, U., Shepherd, J., Turley, C., and Watson, A.: Ocean acidification due to increasing atmospheric carbon dioxide, Royal Society Report, 2005.

Redfield, A. C., Ketchum, B. M., and Richards, F. A.: The influence of organism on the composition of seawater, in: The Sea, 2. Ed., edited by: Hill, M. N., Wiley, 26-77, 1963.

Riebesell, U., Wolf-Gladrow, D. A., and Smetacek, V.: Carbon dioxide limitation of marine phytoplankton growth rates, Nature, 361, 249-251,1993.

Riebesell, U., Schulz, K. G., Bellerby, R. G. J., Fritsche, P., Meyerhöfer, M., Neill, C., Nondal, G., Oschlies, A., Wohlers, J., and Zöllner, E.: Enhanced biological carbon consumption in a high $\mathrm{CO}_{2}$ ocean, Nature, 545-548, doi:10.1038/nature06267, 2007.

Riebesell, U., Zondervan, I., Rost, B., Tortell, P. D., Zeebe, R. E., and Morel, F. M. M.: Reduced calcification of marine plankton in response to increased atmospheric $\mathrm{CO}_{2}$, Nature, 407, 364-367, 2000.

Riebesell, U.: Effects of $\mathrm{CO}_{2}$ enrichment on marine phytoplankton, J. Oceanogr., 60, 719-729, 2004.

Ridgwell, A., Zondervan, I., Hargreaves, J. C., Bijma, J., and Lenton, T. M.: Assessing the potential long-term increase of oceanic fossil fuel $\mathrm{CO}_{2}$ uptake due to $\mathrm{CO}_{2}$-calcification feedback, Biogeosciences, 4, 481-492, 2007, http://www.biogeosciences.net/4/481/2007/.

Sabine, C. S., Feely, R. A., Gruber, N., Key, R. M., Lee, K., Bullister, J. L., Wanninkhof, R., Wong, C. S., Wallace, D. W. R., Tillbrook, B., Millero, F. J., Peng, T.-H., Kozyr, A., Ono, T., and Rios, A. F.: The oceanic sink for anthropogenic $\mathrm{CO}_{2}$, Science, 305, 367-371, 2004.

Sambrotto, R. N., Savidge, G., Robinson, C., Boyd, P., Takahashi, T., Karl, D. M., Langdon, C., Chipman, D., Marra, J., and Codispoti, L.: Elevated consumption of carbon relative to nitrogen in the surface ocean, Nature, 363, 248-250, 1993.

Schulz, K. G., Riebesell, U., Bellerby, R. G. J., Biswas, H., Meyerhöfer, M., Müller, M. N., Egge, J. K., Nejstgaard, J. C., Neill, C., Wohlers, J., and Zöllner, E.: Build-up and decline of organic 
matter during PeECE III, Biogeosciences, 5, 707-718, 2008, http://www.biogeosciences.net/5/707/2008/.

Schuster, U. and Watson, A. J.: A variable and decreasing sink for atmospheric $\mathrm{CO}_{2}$ in the North Atlantic, J. Geophys. Res., 112, C11006, doi:10.1029/2006JC003941, 2007.

Sterner, R. W. and Elser, J. J.: Ecological Stoichiometry, Princeton University Press, Oxford, UK, 2002.

Tanaka, T., Thingstad, T. F., Løvdal, T., Grossart, H.-P., Larsen, A., Allgaier, M., Meyerhöfer, M., Schulz, K. G., Wohlers, J., Zöllner, E., and Riebesell, U.: Availability of phosphate for phytoplankton and bacteria and of glucose for bacteria at different $p \mathrm{CO}_{2}$ levels in a mesocosm study, Biogeosciences, 5, 669-678, 2008, http://www.biogeosciences.net/5/669/2008/.

Tortell, P. D., DiTullino, G. R., Sigman, D. M., and Morel, F. M. M.: $\mathrm{CO}_{2}$ effects on taxonomic composition and nutrient utilisation in an Equatorial Pacific phytoplankton assemblage, Mar. Ecol.Prog. Ser., 236, 37-43, 2002.

Tyrrell, T. and Merico, A.: Emiliania huxleyi: bloom observations and the conditions that induce them, in: Coccolithophores: from molecular processes to global impact, edited by: Thierstein, $\mathrm{H}$. R. and Young, J. R., Berlin, Germany, Springer, 75-97, 2004.
Urabe, J., Togari, J., and Elser, J. J.: Stoichiometric impacts of increased carbon dioxide on a planktonic herbivore, Glob. Change Biol., 9, 818-825, 2003.

Volk, T. and Hoffert, M. I.: Ocean carbon pumps, analysis of relative strengths and efficiencies in ocean-driven atmospheric $\mathrm{CO}_{2}$ changes, in: The Carbon Cycle and Atmospheric $\mathrm{CO}_{2}$ : Natural Variations Archean to Present, edited by: Sunquist, E. T. and Broecker, W. S., Geophysical Monograph Series, Vol. 32, Washington, DC, 99-110, 1985.

Wanninkhof, R. and Thoning, K.: Measurement of fugacity of $\mathrm{CO}_{2}$ in surface water using continuous and discrete sampling methods, Mar. Chem., 44, 189-205, 1993.

Weiss, R. F.: Carbon dioxide in water and seawater: the solubility of a non-ideal gas, Mar. Chem., 2, 203-215, 1974.

Zondervan, I., Rost, B., and Riebesell, U.: Effect of $\mathrm{CO}_{2}$ concentration on the PIC/POC ratio in the coccolithophore Emiliania huxleyi grown under light-limited conditions and different daylengths, J. Exp. Mar. Biol. Ecol., 272, 55-70, 2002.

Zondervan, I.: The effects of light, macronutrients, trace metals and $\mathrm{CO}_{2}$ on the production of calcium carbonate and organic carbon in coccolithophores - A review, Deep-Sea Res. II, 54, 521-537, doi:10.1016/j.dsr2.2006.12.004, 2007. 